\title{
PPARGC1A wt Allele
}

National Cancer Institute

\section{Source}

National Cancer Institute. PPARGC1A wt Allele. NCI Thesaurus. Code C116294.

Human PPARGC1A wild-type allele is located in the vicinity of 4p15.1 and is approximately $149 \mathrm{~kb}$ in length. This allele, which encodes peroxisome proliferator-activated receptor gamma coactivator 1-alpha protein, is involved in transcriptional regulation mediated by steroid and nuclear receptors. 